\title{
Women's stories and knowledge of wildlife and conservation practice in northern Tanzania and South India
}

\author{
Mara J. Goldman, Shruthi N. Jagadeesh \\ Tubulu Meng'oru NGimojino and Lakshim M. Gowda
}

\begin{abstract}
Around the world, Indigenous peoples have stories about wildlife that reflect knowledge and feelings about animals and their relationship to humans. Different people's experiences speak to the variety of interactions people have with animals in the spaces where humans and non-human animals live and interact. These stories are often told by women, reflecting the ways in which gender mediates human-environment relations. Yet gendered differences in knowledge and experience are rarely addressed in wildlife conservation research and action. Even community-based conservation efforts often ignore or marginalize the knowledge and experiences of women. We present women's stories and experiences of wildlife from Maasai communities in Tanzania and Soliga communities in India. We show that women have the desire and knowledge to participate in conservation decision-making but are currently marginalized from community conservation practice. We argue that including women in research and action is key for successful community-based wildlife conservation.
\end{abstract}

Keywords Gender, India, Maasai, Soliga, stories, Tanzania, wildlife conservation, women

\section{Introduction}

Cholars have argued that community involvement can $\checkmark$ lead to more efficient and socially just environmental management and conservation practice (Gadgil et al., 1993; Western et al., 1994; Andrade \& Rhodes, 2012; Kothari et al., 2013; Oldekop et al., 2016). Yet, community conservation approaches have been widely criticized for uneven distribution of benefits (Thompson \& Homewood, 2002), superficial participation and limited inclusion of local knowledge (Agrawal \& Ribot, 1999; Goldman, 2011).

MARA J. Goldman (Corresponding author, (1) orcid.org/0000-0001-9864-256X) and Shruthi N. Jagadeesh Department of Geography, University of Colorado Boulder, 260 UCB Boulder, Colorado 80309-0260, USA

E-mail mara.goldman@colorado.edu.org

Tubulu Meng'oru Ngimojino Oltukai, Tanzania

LAKSHMI M. GowDA Ashoka Trust for Research in Ecology and the Environment, Bangalore, India

Received 8 July 2020. Revision requested ${ }_{13}$ October 2020.

Accepted 12 March 2021. First published online 22 September 2021.
Communities are often homogenized and romanticized as undifferentiated actors, ignoring differences in gender, class, ethnicity, caste and livelihood, which reinforces existing inequalities (Agrawal \& Gibson, 2001). Wildlife conservation in particular, with its heavy focus on large mammals and anti-poaching patrols, promotes male hierarchies of knowledge and power, with women often excluded or marginalized from projects (Hunter et al., 1990; Doubleday, 2020). We argue that community conservation needs to include a deeper appreciation of different ways of knowing and relating to wildlife within and across communities, particularly along gendered lines. We promote the value of storytelling practices within communities to uncover the various relations with wildlife that have thus far been mostly overlooked.

The relationship between gender and the environment has been well established in both research and policy. Gender was acknowledged as a key factor in Principle 20 of the 1992 Rio Declaration, which states 'women have a vital role in environmental management' and that their 'full participation is therefore essential to achieve sustainable development' (cited in Ogra, 2012, p. 408). Gender mainstreaming was adopted by many development organizations to address the needs of women along with those of men at every stage of project development (Dawson, 2005; Mukhopadhyay, 2016). Scholars have noted that environment-society relations are mediated through gender and other categories of social difference as tied to labour, rights, responsibilities, knowledge and social-spiritual relations (Agarwal, 1992), particularly in feminist political ecology (Rocheleau et al., 1996; Elmhirst \& Resurreccion, 2008; Nightingale, 2017). Some have criticized gender mainstreaming for its unequal application in practice, and reproduction of binary gender categories (Asher \& Varley, 2018; Elias et al., 2020). Unfortunately, many wildlife conservation organizations have not taken up either gender mainstreaming or scholarly critiques, seeing gender as outside the specific goals of wildlife conservation (Ogra, 2012).

Yet research has shown that wildlife conservation practice is gendered, with the costs and benefits from conservation projects and human-wildlife conflicts unequally distributed across gender lines (Ogra, 2008; DeMotts \& Hoon, 2012; Pascual et al., 2014). Women are often excluded as knowledgeable agents in community wildlife projects (Hunter et al., 1990), which can lead to both physical and 
psychological costs (Doubleday, 2020). Women frequently have different conceptualizations of social well-being (Milner-Gulland et al., 2014; Woodhouse \& McCabe, 2018), and attitudes towards wildlife (Kellert \& Berry, 1987; Roque de Pinho et al., 2014; Mkonyi et al., 2017), and participate less in community decision-making processes (Keane et al., 2016) and wildlife ranger activities (Seager et al., 2021). Scholars of feminist political ecology have illustrated how gendered differences in nature-society relations are enacted, reinforced and challenged, but have rarely addressed relations with wildlife. Hovorka (2015) argued for more integration of feminist scholarship and animal studies, to move beyond a focus on gendered impacts of wildlife and conservation towards analyses of gendered experiences, knowledge and feelings about wildlife.

We attend to that call here, while highlighting the importance of stories as told by Indigenous communities (Fernández-Llamazares \& Cabeza, 2018), and women in particular (Rocheleau, 1991), as normative devices that explain relationships, feelings, beliefs and knowledge about the natural world (Kimmerer, 2013). As Indigenous scholaractivist Leanne Simpson stated (2017, p. 20), 'theory and praxis, story and practice are interdependent, cogenerators of knowledge'. Not all members of communities tell, hear and practice the same sets of stories.

We present stories and experiences from women in two areas where wildlife conservation has a strong historical presence alongside Indigenous resource-dependent populations: Maasai in the northern Tanzanian rangelands and Soligas in South Indian forested highlands. We present these cases neither for direct comparison nor for generalizability, but to draw from the experiences of MJG and SNJ as female researchers investigating similar patterns in different locations. Mara Goldman has worked with Maasai in Tanzania and Kenya for over 2 decades. She started work in India exploring how different knowledge and experiences were addressed in the community conservation work of a teaching/research/action NGO and was surprised to find gender as a category often marginalized or ignored. Shruthi Jagadeesh shared this experience, as she worked with tribal forest communities as part of the research and outreach campaigns of local environmental research organizations in South India. As women, we were interested in hearing from women, and particularly attuned to their minimal presence and participation at meetings and in research as subjects or assistants.

In addition to our personal research experiences, the two locations share similarities and have differences that make their inclusion in a joint study significant. Exclusionary wildlife conservation practices and laws, upheld today by global conservation organizations, were introduced to India and Tanzania with British colonialism. Both areas are home to resource-dependent residents, biodiversity hotspots, and long-term conservation activities. Indigenous populations in both locations have long been advocating for greater involvement in conservation along with greater land tenure security. In India, the Scheduled Tribes and Other Traditional Forest Dwellers (Recognition of Rights) Act of 2006, commonly referred to as the Forest Rights Act, is being utilized for both purposes, although its implementation has been minimal and contested (CFR-LA, 2016). In Tanzania, national land laws are being used to prioritize tenure security for villages, but national conservation legislation works against real devolution of rights and responsibilities (Benjaminsen et al., 2013). Little if any attention has been paid to the gendered nature of wildlife conservation in either locale. We argue that without the active participation of women in research and action, their specific knowledge and experiences remain overlooked, weakening the effectiveness of and support for conservation.

Much of the research and conservation work in both communities has focused on men, who are often assumed to be the cultural and political leaders, traditional knowledge holders and decision makers responsible for the labour of herding, hunting, farming and managing the land, with women assumed to have limited rights or desires to engage with affairs outside the home (Hodgson, 2001; Ogra, 2012). Not only is this a superficial understanding of the complex gender dynamics mediating social relations within Maasai and Soliga communities, where micro-power dynamics determine interpersonal relations at different scales, across clans, age, wealth and location, but much is also changing in both places (Goldman \& Little, 2015; Venkatesh et al., 2020).

Drawing from our own data and the work of others, we suggest that these underlying assumptions about gendered differences in experience and expertise often drive the exclusion of women from wildlife conservation projects. We present preliminary findings about these assumptions and an overview of the limited and changing levels of participation of women in community conservation. We then challenge the assumptions, by presenting Soliga and Maasai women's stories and observations, experiences, and knowledge about wildlife. We do this not to essentialize women in these spaces, but to present a case for the need to include women in conservation. We do this broadly, and use our conclusion to suggest ways to take the complexity of gender seriously in community-based wildlife conservation.

\section{Study areas}

Research was conducted in the Tarangire-Manyara Ecosystem of Tanzania (Fig. 1) during 2004-2019, and in the Biligiri Ranganathaswamy Temple Tiger Reserve in India (Fig. 2) during January-June 2018 and June-August 2019 and with conservation research and activist NGOs across the country. 


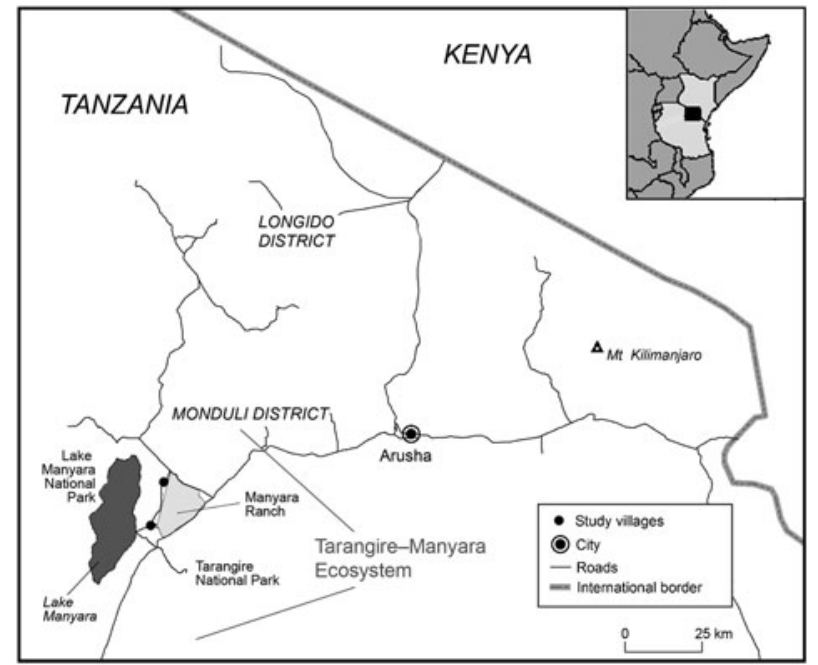

FIG. 1 General Location of the Tarangire-Manyara Ecosystem, northern Tanzania.

The Tarangire-Manyara Ecosystem is a conservation landscape that includes one of the highest densities of animal biomass and a large lion Panthera leo population (Kissui, 2008), and is also home to 80-100 villages and $300,000-400,000$ people of various ethnicities (Bluwstein, 2018). Research was conducted in two predominantly Maasai villages located within a wildlife corridor area between Lake Manyara and Tarangire National Park, and adjacent to the Manyara Ranch, a community conservation area established in 2002 by the African Wildlife Foundation and Tanzanian Land Conservation Trust. Pastoralism is the primary livelihood of resident Maasai, supplemented with small-scale rain-fed cultivation, wage labour (e.g. as guards in the city, game scouts and herders in Manyara Ranch), and small business ventures. Although Maasai have historically shared the rangelands with migratory wildlife (Reid, 2012), increased cultivation, land loss, sedentarization, and climate change are challenging the ability of people and wildlife to live together (Galvin et al., 2008), which is leading to an increase in community conservation activities in the area.

Biligiri Ranganathaswamy Temple Tiger Reserve in Karnataka State, South India, is well known for its rich biodiversity and as prime habitat for the tiger Panthera tigris (Karanth \& DeFries, 2010). It has been home to the Soliga Tribe for at least 3 centuries, an adivasi community that has 'had a continuous and intimate interaction with the forest, deriving most of their basic requirements such as food, fodder, fuel, fruit and fibre from the forest' (Madegowda, 2009, p. 65). The forest was designated as a Wildlife Sanctuary in 1974, with several Soliga villages resettled in the late 1970s, and as a Tiger Reserve in 2011, which increased restrictions on Soliga mobility (Venkatesh et al., 2020) and use of the forest (Rai et al., 2019). In October 2011, however, Soligas in the Biligiri Ranganathaswamy Hills secured legal rights through the Forest Rights Act

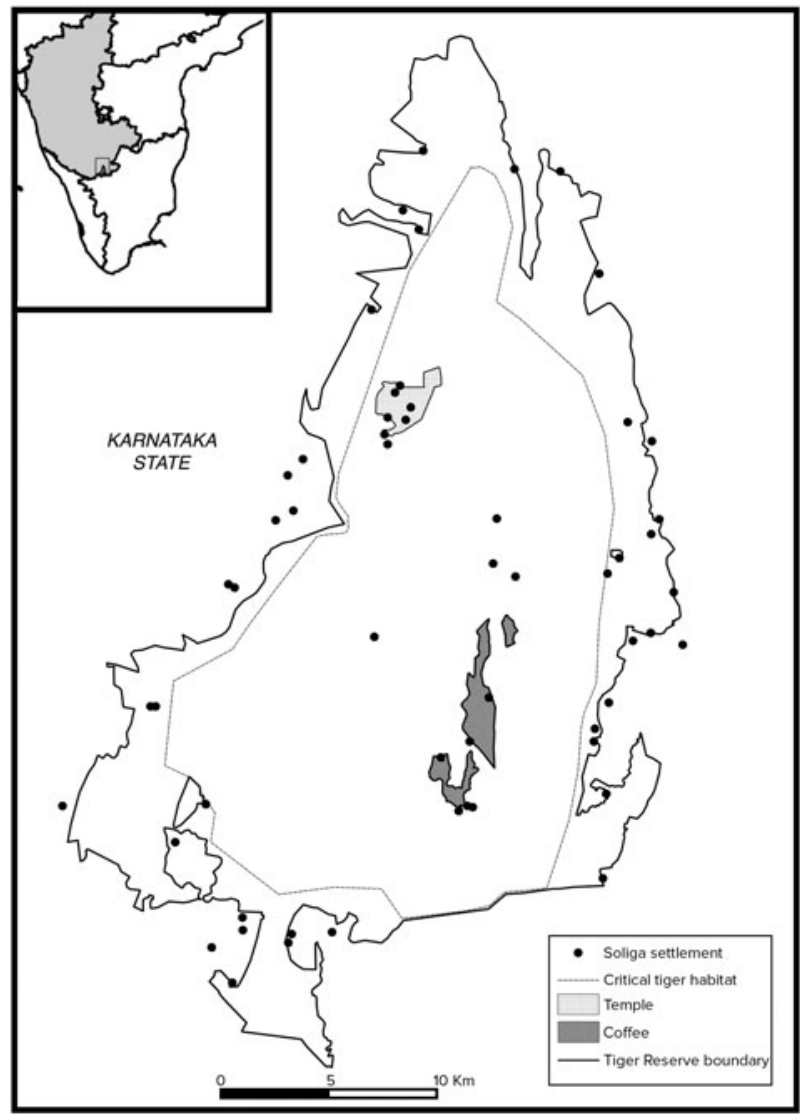

FIg. 2 The Biligiri Ranganathaswamy Temple Tiger Reserve in the state of Karnataka, south-west India.

(Madegowda \& Rao, 2017), including rights to cultivation, collection of forest produce, grazing, forest conservation, access to sacred sites, and land titles. This was the first tiger reserve in India where forest dwelling communities received forest rights. The area has received a great deal of academic attention, including research on Indigenous ecological knowledge, impacts of bans on traditional management practices, and socio-economic and agricultural changes (Setty et al., 2008; Mandal et al., 2010; Mundoli et al., 2016; Thekaekara et al., 2017). Much of this research has depicted Soligas as a homogenous community, and little research on the region has explicitly addressed gender.

\section{Methods}

Ethnographic observations and open-ended interviews were the primary source of data in both locations. In 2018, in the Biligiri Ranganathaswamy Hills in India we conducted 36 interviews with Soligas (22 women, six men, eight youth) about labour, knowledge and experiences with wildlife, and knowledge about forest rights laws and participation in conservation meetings and activities. We observed one community organization meeting and one women's meeting in winter/spring of 2018 and conducted informal 
interviews with participants afterwards. We also conducted open-ended interviews and participant observation with students and research fellows across socio-economic strata at a conservation research/action organization during January-May 2018, including 11 students (seven women), two women postdoctoral fellows, and eight senior fellows (three women) about their personal life stories, including research, work and education and their feelings about gender and caste as related to conservation. In 2019, we conducted phone and in-person interviews with eight conservationists (four women) working in prominent NGOs to ask about gendered assumptions and the integration of gender in their work. Interviews were conducted in Kannada in villages by SNJ and LMG, and in English with NGO workers and students by MJG and SNJ.

In Tanzania we draw from $>2$ decades of research by MJG on conservation politics and Maasai knowledge about wildlife, including participant observation at hundreds of meetings and informal interviews with residents (2002-2004, January-May 2005, October 2006-July 2007, January-July 2009). In the summer of 2018, we conducted one focus group interview with seven young men, and one with 23 women, and informal interviews with local informants (five men, three women) about changes in conservation management. In 2019 we conducted specific followup interviews regarding women's stories about wildlife and changes in conservation management with 10 women. Interviews were conducted in a mixture of Swahili and Maa and translated from Swahili into English by MJG, and from Maa to Swahili and English by TMN.

\section{Results}

In both India and Tanzania, we found that women were not included in conservation work or research to the same extent as men, although this is beginning to change, and that women in both locations have a great deal of knowledge about their environment, which they pass on through teachings, songs, stories and daily labour practices.

\section{Participation in conservation management}

In both locations, women were only marginally involved in conservation-related research and decision-making, albeit with changes underway. Informal interviews with colleagues and students working on conservation in India revealed long-standing assumptions that women were shy or too busy to attend meetings. Gender was a topic covered in sociology class, not something to worry about in the field. In Tanzania conservation practitioners reflected similar sentiments and suggested that Maasai women were not able to speak in front of men, did not know much about wildlife because they did not travel far from home, and should be included in conservation through women's projects such as cultural tourism, beadwork, and beekeeping activities. In both places, a couple of female representatives were often believed to be able to represent all women at meetings.

Interviews with wildlife conservation professionals in India also revealed that similar assumptions guided many of their decisions and led to a lack of inclusion of women in their work. All acknowledged that women were underrepresented in their work and gender was poorly addressed. One female interviewee suggested this was related to wildlife conservation itself being masculine:

Large cat biology is all about territory, the wild, an animal that needs its own space and is only found in certain places. That's a very masculine way of looking at it!

Others explained the lack of women's involvement as related to gender relations within communities. One woman said she felt safer with male field assistants, who were also more confident in the field. Others said that female field workers were unable to interact with as many community members, and another explained it as the natural division of labour:

Field assistants are men, we don't have women. It is more convenient, because of the nature of the job. In the weaving centre we have women, but for the work that includes a lot of walking in the field it is mostly men.

Multiple respondents also suggested that women just did not know about wildlife, as reflected in the statement: 'Women are really busy, preoccupied with housework. They don't often go into forests and won't know about wildlife.'

In the Tiger Reserve, women consistently remarked that few people from conservation and development NGOs spoke to them. Interdisciplinary researchers working in the area confirmed they interacted almost exclusively with Soliga men. They explained this as related to personal constraints preventing them from talking with women, but also suggested that women did not go to the forest as much as men, and were held back by traditional leaders, who were men. Many Soliga women agreed that women were often afraid to talk in front of strangers, or in large groups, particularly in meetings dominated by men. Our own observation of a meeting of a non-timber forest product (NTFP) group illustrated this: few women were present, and they scarcely spoke. When we asked why this was the case, a prominent older woman who goes to many such meetings explained:

Women think slowly, they take time to think about what to say. That meeting was all about other things, if they had spoken about how much NTFP is coming in, from where, we could have participated.

When we asked other women in the Reserve why they did not participate in meetings, some said it was because they were held at inconvenient times or locations. Yet most agreed that they should be included in conversations about forest management. When asked what they could contribute, one woman explained: 
Women know a lot about the forest. After all, they go each and every day to the forest. If you call them for meetings, they will come and then you can ask them about what is happening in specific forests. But they are not called so much, they won't know that they can come for the meetings.

Other women said they would suggest reinstating practices from before the area became a Wildlife Sanctuary, including planting tubers and fruit trees in the forest that animals could also eat, removing invasive Lantana species, and using fire to manage the forest. Women insisted the forest was their home, despite their inability to manage it since it had become a protected area. They spoke about being intimately connected to the forest and dedicated to protecting it. As one group of women stated when asked if they were interested in conservation, 'the idea of conservation is within all of us-men, women, all of us! We can't live without the forest and we won't.'

Many of the women we spoke with in India and Tanzania were interested in participating in conservation and suggested that researchers and NGOs should call women-only meetings to make it easier for more women to participate, or give women the agenda in advance. In both places, women were meeting to form groups to address micro-finance and development issues, often assisted by state agencies or development NGOs. Although questions of wildlife conservation were rarely addressed at these meetings, some Soliga women's groups were beginning to talk about forest management issues and lamented they were not approached by outside organizations working on forest rights or wildlife conservation. In Tanzania, Maasai women, aided by civic education on land rights, leadership and empowerment, used their community groups to initiate a grievance against what they saw as injustices associated with the new community conservation area, the Manyara Ranch (Goldman \& Little, 2015).

Formally, over the last 2 decades we have observed that Maasai women's participation in community-based conservation activities in the study villages usually took two forms: one or two women (often selected by men) on a committee, and income-generating projects specifically for women initiated by a conservation NGO or tourism agency, such as selling beadwork or dancing for tourists. Yet at the same time, women have been actively participating in NGOlead development and education activities where they have gained leadership skills, literacy and knowledge about their rights to land titles. Additionally, new legal structures in Tanzania prescribe a quota of women at village meetings and on land committees, leading to an increased involvement of women in land issues. These combined forces gave women in the study villages strength to address their concerns related to the Manyara Ranch.

The Manyara Ranch has a contentious political history, with the two study villages claiming original ownership rights. When it was first created as a conservation area in 2002, there were no women on the board charged with running the Ranch, and only two women (who never spoke at meetings) on an eight-member steering committee representing the two villages. In 2013, after learning about their rights to land titles from a local Maasai-led development organization, women in one village led a movement to request the title for the Ranch be returned to the two villages. They met on their own and organized village-wide meetings to draft a letter to the Member of Parliament (also the chairman of the board), requesting the title be returned. They also demanded rights to graze during the dry season, care for wildlife themselves, have a tourism venture on village land, and produce an environmental management plan.

In 2016 the title of Manyara Ranch was revoked from the conservation agency and turned over to the district government. The two villages remain beneficiaries, but with more power than they had under the previous title. In 2018, two women were placed both on the board and on the steering committee. That same year, when a group of 23 Maasai women were asked how the Ranch should be run and by whom, they said the process should involve women and men. They further explained that 'we women have to participate in every single activity to make sure that women's ideas will not be ignored. Any board or committee that will be formed, women should be given seats.' They said that women could participate in meetings, to propose ideas and offer opinions. An elderly woman noted that this was different from the past: 'in the past, we didn't participate, nor were we given a chance to be nominated to lead the community, because women were very much scorned.' A group of six women stated that today they have a chance to be selected for leadership positions and to present their ideas at meetings. They were hopeful these changes would lead to real opportunities for employment, particularly for the growing number of educated young women in both villages, participation in resource management, and for truthful information regarding ranch management to reach community members. Yet, there are only two women on the steering committee, and most outside conservation agencies working in the villages continue to hire men as wildlife guides and game scouts. In doing so, the valuable knowledge and experience that women have regarding wildlife goes unnoticed. We present some of that knowledge below, mostly in the form of stories.

\section{Knowing wildlife through stories and experience}

Prior work in Tanzania and Kenya showed that Maasai women shared stories about lions protecting women and children; stories that usually end with an offering of a slaughtered animal to the lion, and letting it go in peace, as covered in Goldman et al. (2010):

There was a woman who travelled to a temporary boma [homestead] with a child on her back. On the way a lion walked ahead and then behind her, as if he was trying to stop her. She was tired. She placed her child on the ground, thinking this would appease the lion, and 
continued on her way. When she reached the boma she was in tears and explained to the elders that there was a lion and she was afraid. Ilmurran [young men of the 'warrior' age-set] followed her tracks back and found the lion, with the child still sitting at its feet. The lion was trying to stop another lion from killing the child. The mother felt so ashamed that she offered her own breast milk [a sign of peace and forgiveness] to the lion. The ilmurran went to fetch a goat and gave it to the lion to eat.

Another story tells of a woman travelling to her father's home. She stopped along the way, tired and hungry, to pray for help. She had a small child with her and put it down on the path. A lion, seeing the mama and her child, killed a gazelle and brought it to the mama to feed her child. After hearing this story, the young men who had wanted to kill the lion, instead offered it a goat.

In 2019 we were told the following by a group of elderly women:

The lion is an animal that helps and cannot harm women. Women are the main ones responsible for looking for firewood to cook with and charcoal to use. Here, long ago, when women would go to the bush to look for firewood if there was a lion, the lion would inevitably break a branch to let the women know of its presence. But if we were men? Then the lion would not do this, but rather the lion would start to move away because it understands that men are their enemy, therefore it can start a fight any time at all, because long ago the ilmurran would walk with weapons for war. Ilmurran are the big enemy of lions as they are indeed the guards to protect livestock (cattle, sheep, goats).

Yet men's relations with lions are also nuanced and complex. This same group of women told a story about an injured lion that was helped by an olmurrani [warrior] of the Mamasita clan, who put his own life at risk by attending to the lion, to take a thorn from his paw. The story ends by explaining that, 'after a little while the olmurrani succeeded at removing the thorn. He left, and the lion went on his way. This is when the friendship began. That is why a lion cannot eat an olmurrani of this clan unless there is someone who is cursed by his parents or the elders for wrongly treating the lions.'

Even when lions are hunted by Maasai, it is seen as a battle of equals, where either the lion or the Maasai may face a loss. As a group of elderly women explained to us in 2019, 'long ago, when the sun was rising, the women would pray and would say, "If it is not a child of a lion that is killed, then it will be the child of a Maasai, so either way, we must pray."

The above stories reflect feelings about and relations with lions; expectations of behaviour that show respect for lions and see them as individuals, and similar respect by lions for people (if both groups act accordingly). Other stories about animals reflect their role in mediating human-human as well as human-animal relations. One story explains that when women are married, they are told they should not look back when they walk to their new home, lest they turn into an elephant. 'That is why we say elephants are women who looked back on the day they were taken to their husbands', one elder woman explained. Similar stories are told by Maasai in Kenya to explain the presence of elephants (Roque dePhino, pers. comm., 2020).
A Soliga woman and her teenage daughter also told us a story of the origin of elephants stemming from the strife of a new bride:

Many years ago, a new daughter-in-law came to the boy's house. They were growing different kinds of millet and betel nut, and they used to grind and pound and then eat it. The mother-in-law would give the grain to the daughter-in-law and ask her to grind it every day while she would just relax. How tired would the daughter-in-law get, imagine! Doing this every day! In those days they had huge vessels and sieves for the grain. One day she got so tired of it, that when the mother-in-law had gone to the fair (at that time they had to walk through the forest), she got tired of pounding and took the pounding stick and made it into the trunk of the elephant. The sieve (shaped like a dustpan) became the ears. The millet storage basket was the stomach. She placed all of this under the bamboo tree... It was then time. Soon it became an elephant and came to life. Then it picked up a big seegekai [Acacia concinna] seed. When the mother-in-law came back, the elephant killed her for torturing the daughter-in-law and then went off into the forest. That's why there are elephants in the forest today.

Soliga women also sing specific songs at festivals or during the harvest season about their social and natural worlds. As an elder woman explained, 'it is mostly the women who tell stories and sing. Every forest has a story, the names, the things that happened there. Trees also have stories.'

We found that Soliga women's labour practices also contributed to knowledge and observations about wildlife, both in the forest and in their homes. Nearly all the women we spoke with stated that men and women shared the work of both forest collection and cultivation. As articulated by one woman, 'men and women access the forest equally, there are no places where only some go'. Women explained that when collecting honey or gooseberries, men climbed the trees and women collected lower down. Women also expressed concerns over reduced availability of honey, which they explained as related to biodiversity loss resulting from the suppression of traditional Soliga fire management by the forest department.

Gendered divisions of labour in the Tiger Reserve have shifted over time as a result of increased restrictions on forest access and the suppression of traditional management strategies. Soliga are now largely dependent on wage labour, which is mostly given to men, leading women to use the forest more regularly, including daily grazing of livestock and other forest-related activities. This is heightened during the fire season (summer) when Soliga movements are highly monitored. As one woman explained:

During the fire season it is difficult to go into the forest. Now with reduced rain and after the Lantana [an invasive plant] has taken over, there is no water, making it even more difficult to go into the forest. It is easier for women. Women don't smoke so they are not suspected of lighting fires. Women also only take small things for the home like firewood or tubers. Men are the ones who collect the bigger things, so they cannot go as freely.

When women are in the forest, they often encounter wildlife. One woman described with excitement her observations about various wildlife:

We see lots of elephants, bears and deer. I saw a $7 \mathrm{ft}$ long python! It had just swallowed a bird and it was sitting on a tree. They stay on the tree till all the bones digest and then whatever they can't digest comes out of 
their mouths. There was one near the big Sampige tree there. I have also seen Russell's vipers; they are fat and make a loud noisebushhhhh. There are leopards near the rock next to the road. They just watch us and go away; we don't have any issues with them.

When we spoke with women about wildlife, they spoke more with respect than with fear, as illustrated in the following two statements shared during an interview with an old grandmother and her daughter, respectively:

There is one road where we do festivals and puja (prayer); if you keep walking you will reach a rock. Near that rock is a path where elephants, deer, tigers go. If we come across animals in the forest, we must mind our own business, they will mind their own. For elephants we have to make a lot of noise and scare them away. Bears are trickier so it's better to just be quiet and avoid them. If we see a tiger, we just have to stand and watch from a distance. They will only do something to us if we do something to them, and if we just sit quietly it goes off calmly.

I have seen plenty of [tigers] inside the forest. Once, one tried to catch a goat. I turned and saw it and it was running with the goat in its mouth. I ran after it and held on to the back leg of the goat and screamed at the tiger. The tiger let go and ran inside [the forest]. It didn't do anything to me, and I had nothing in my hand, not even a machete. Later someone else came and helped me to wrap up the goat and carry it home.

Maasai women also encountered wildlife whilst herding small stock, collecting water, firewood, grasses for their houses, and medicinal plants, and tending to their farms. Although men are mostly in charge of herding cattle, women tend to small stock and family farms. In mapping exercises women mapped places where lions hide, elephants move, and wildebeest migrate. Women also observed wildlife that come to their farms and discussed at length those they can chase away (zebra Equus quagga, ostrich Struthio camelus) and those they cannot such as elephants and monkeys, with the latter, one elderly woman explained, 'act[ing] just like people, collecting the maize and carrying it over their shoulders!' Many women we spoke with could explain in detail the water needs of animals and their subsequent movement patterns in search of water and green grass. They watched wildebeest movements closely to make sure that small calves did not mistakenly run off with the migrating herds. Similar to Soligas in the Tiger Reserve, most Maasai families are dependent on wage labour, which is almost exclusively given to men, including the growing number of community game scouts employed by conservation NGOs. Women supplement their income through microdevelopment loans, sale of foodstuffs at local markets, and beadwork at handicraft markets associated with tourism.

\section{Discussion}

We have shown that women living in and around protected areas in northern Tanzania and South India have stories, experiences and feelings about wildlife that reflect complex relations and expectations of mutual respect. However, despite an extensive literature on both community conservation and gender and the environment, questions of gender in wildlife conservation have been poorly addressed. Our research addresses this neglect and also examines practical ways in which gender imbalances within conservation can be addressed. Although we did this by drawing comparisons from two locations in the Global South, our intention is not to suggest that all women everywhere, or within the Global South, are a homogenous group. We recognize that differentiations exist among women within and across locations, and support the call by scholars of feminist political ecology to attend to these differences in both research and action. Our work specifically seeks to address a gap in both research and practice, and to promote in-depth exploration of the ways in which women know about, experience and feel about wildlife while also asking how wildlife conservation can better reflect these real differences in community conservation endeavours.

Women as a social group have not been included in conservation-related research and action to the same extent as men. Our preliminary findings suggest that assumptions from conservation actors regarding gendered norms, divisions of labour, and women's roles in the public sphere are a significant factor in their exclusion. Yet, we have also shown that gendered divisions of labour do not keep Maasai and Soliga women from interacting with wildlife when they collect firewood, water, forest produce, medicinal plants, or attend ritual events. Divisions of labour and social norms are also changing, with women in both places participating more in herding, NTFP collection, farming, politics and meetings. Thus, although local gendered norms and responsibilities may limit women's participation in certain activities and meetings, this is neither static nor universal. Additionally, gender relations within communities, and the challenges they may present, can be better navigated by outsiders. Meetings can be held at times and locations that make women's participation easier. Women-only meetings can be held, or women can be given the agenda in advance, so they can plan ahead and choose someone to speak who is comfortable doing so. Social differences such as age, class, education, clan and political or NGO connections will influence the kinds of involvement women have in meetings, and those who have something to contribute may not always be the ones who feel comfortable speaking out. These differences matter and suggest that blanket assumptions about women's inability to participate, or lack of knowledge on a subject (such as wildlife) are unwarranted. Additionally, participation in women's groups in both locations are leading to more women being able to speak freely in front of men and outsiders. Importantly, we found that women of various ages and status want to be included in conservationrelated activities.

There is increasing evidence that successful conservation requires equitable inclusion of a range of community members (Cetas \& Yasué, 2016), including women (Ogra, 2012). And there is a growing awareness of the importance of women in wildlife conservation leadership and action, as 
evidenced by the Women in Conservation Leadership Training pre-conference as part of the Human Dimensions of Wildlife annual conference in Kenya in 2020, and the new Maasai all-women ranger team in Kenya, Team Lioness (IFAW, 2021). Supporting such efforts, we argue that conservation practice must account for different ways of knowing and relating to wildlife and their conservation, including across social categories within communities. This includes different ways of communicating knowledge, such as through stories. Our research has begun to explore some women's knowledge about wildlife, and how that knowledge is shared. We have focused on stories as a format often overlooked by conservation researchers and practitioners, but vital for knowledge production, exchange and practice in many communities. Stories convey social norms and reinforce human and human-animal relations. Conservation researchers and practitioners could learn from stories that circulate within communities and build on them for more sustainable and equitable conservation outcomes.

Acknowledgements Work in India was supported by a FulbrightNehru scholarship, the assistance of Nitin Rai and Siddappa Setty, and the field staff and community members at Biligiri Ranganathaswamy Temple Tiger Reserve. In Tanzania we thank the Commission for Science and Technology, and the villagers of Oltuka and Esilalei. We thank Angshuman Das for help with the map figures, and a seed grant from the University of Colorado Boulder Center to Advance Research and Teaching in the Social Sciences for supporting our work on gender and conservation.

Author contributions Study design, fieldwork: MJG, SWJ; data collection in India: LMG, SWJ, MJG; data collection in Tanzania: TMN, MJG; data analysis, writing: MJG, SWJ.

\section{Conflicts of interest None.}

Ethical standards This research abided by the Oryx guidelines on ethical standards, followed the standards of the Social Research Association, and adhered to ethical standards for research with human subjects. Research clearance for data collected in communities in Tanzania and India was obtained from the University of Colorado Boulder Institutional Review Board and confirmed with local authorities in country.

\section{References}

Agarwal, B. (1992) The gender and environment debate: lessons from India. Feminist Studies, 18, 119-158.

Agrawal, A. \& Gibson, C. (2001) Communities and the Environment. Rutgers University Press, New Brunswick, USA.

Agrawal, A. \& Riвот, J. (1999) Accountability in decentralization: a framework with south asian and West African cases. The Journal of Developing Areas, 33, 473-562.

Andrade, G.S.M. \& Rhodes, J.R. (2012) Protected areas and local communities: an inevitable partnership toward successful conservation strategies? Ecology and Society, 17, 14.

Asher, K. \& Varley, G. (2018) Gender in the jungle: a critical assessment of women and gender in current (2014-2016) forestry research. International Forestry Review, 20, 149-159.
Benjaminsen, T.A., Goldman, M.J., Minwary, M.Y. \& Maganga, F.P. (2013) Wildlife management in Tanzania: state control, rent seeking and community resistance. Development and Change, 44, 1087-1109.

Bluwstein, J. (2018) From colonial fortresses to neoliberal landscapes in northern Tanzania: a biopolitical ecology of wildlife conservation. Journal of Political Ecology, 25, 144-168.

CFR-LA (Community Forest Rights-Learning and Advocacy) (2016) Promise and Performance: Ten Years of the Forest Rights Act in India. cfrla.org.in [accessed 23 March 2021].

CetAs, E.R. \& YASUÉ, M. (2016) A systematic review of motivational values and conservation success in and around protected areas. Conservation Biology, 31, 203-212.

Dawson, E. (2005) Strategic gender mainstreaming in Oxfam GB. Gender \& Development, 13, 80-89.

DeMotts, R. \& Hoon, P. (2012) Whose elephants? Conserving, compensating, and competing in Northern Botswana. Society \& Natural Resources, 25, 837-851.

Doubleday, K.F. (2020) Tigers and “Good Indian Wives": feminist political ecology exposing the gender-based violence of humanwildlife conflict in Rajasthan, India. Annals of the American Association of Geographers, 110, 1-19.

Elias, M., Grosse, A. \& Campbell, N. (2020) Unpacking 'gender' in joint forest management: lessons from two Indian states. Geoforum; Journal of Physical, Human, and Regional Geosciences, 111, 218-228.

Elmhirst, R. \& Resurreccion, B.P. (2008) Gender, environment and natural resource management: new dimensions, new debates. In Gender and Natural Resource Management: Livelihoods, Mobility and Interventions (eds B.P. Resurreccion \& R. Elmhirst), pp. 3-22. Routledge, London, UK.

FernándeZ-Llamazares, Á. \& Cabeza, M. (2018) Rediscovering the potential of indigenous storytelling for conservation practice. Conservation Letters, 11, e12398.

Gadgil, M.F., Berkes, F. \& Folke, C. (1993) Indigenous knowledge for biodiversity conservation. Ambio, 22, 151-156.

Galvin, K.A., Reid, R.S., Behnke, R.H. \& Hobbs, N.T. (2008) Fragmentation in Semi-Arid and Arid Landscapes: Consequences for Human and Natural Systems. Springer, Dordrecht, The Netherlands.

Goldman, M. (2011) Strangers in their own land: maasai and wildlife conservation in northern Tanzania. Conservation and Society, 9, 65-79.

Goldman, M.J. \& LitTLE, J.S. (2015) Innovative grassroots NGOS and the complex processes of women's empowerment: an empirical investigation from northern Tanzania. World Development, 66, 762-777.

Goldman, M., Roque de Pinho, J. \& Perry, J. (2010) Maintaining complex relations with large cats: Maasai and lions in Kenya and Tanzania. Human Dimensions of Wildlife, 15, 332-346.

Hodgson, D.L. (2001) Once Intrepid Warriors: Gender, Ethnicity, and the Cultural Politics of Maasai Development. Indiana University Press, Bloomington, USA.

Hovorka, A.J. (2015). The gender, place and culture Jan monk distinguished annual lecture: feminism and animals: exploring interspecies relations through intersectionality, performativity and standpoint. Gender, Place \& Culture, 22, 1-19.

Hunter, M.L., Hitchсоск, R.K. \& Wyскоff-Baird, B. (1990) Women and wildlife in Southern Africa. Conservation Biology, $4,448-451$.

International Fund for Animal Welfare (IFAW) (2021) Team Lioness - Kenya. ifaw.org/projects/team-lioness [accessed 21 June 2021].

Karanth, K.K. \& DeFries, R. (2010) Conservation and management in human-dominated landscapes: case studies from India. Biological Conservation, $143,2865-2869$. 
Keane, A., Gurd, H., Kaelo, D., Said, M.Y., de Leeuw, J., Rowcliffe, J.M. \& Homewood, K. (2016) Gender differentiated preferences for a community-based conservation initiative. PLOS ONE, 11, eo152432.

Kellert, S. \& Berry, J.K. (1987) Attitudes, knowledge, and behaviors towards wildlife as affected by gender. Wildlife Society Bulletin, $15,363-371$.

Kimmerer, R.W. (2013) Braiding Sweetgrass: Indigenous Wisdom, Scientific Knowledge and the Teachings of Plants. Milkweed Editions, Minneapolis, USA.

KIssui, B.M. (2008) Livestock predation by lions, leopards, spotted hyenas, and their vulnerability to retaliatory killing in the Maasai steppe, Tanzania. Animal Conservation, 11, 422-432.

Kothari, A., Camill, P. \& Brown, J. (2013) Conservation as if people also mattered: policy and practice of community-based conservation. Conservation and Society, 11, 1-15.

Madegowda, C. (2009) Traditional knowledge and conservation. Economic and Political Weekly, 44, 65-69.

MADEgOWDA, C. \& RAO, C.U. (2017) Impact of forest policies and the economy of the Soliga tribal's in Biligiri Rangaswamy temple wildlife sanctuary, South India. Journal of Historical Archaeology \& Anthropological Sciences, 1, 4-9.

Mandal, S., Rai, N.D. \& Madegowda, C. (2010) Culture, conservation and co-management: strengthening Soliga stake in biodiversity conservation in Biligiri Rangaswamy Temple Wildlife Sanctuary, India. In Sacred Natural Sites: Conserving Nature and Culture (eds B. Verschuuren, J. McNeely, G. Oviedo \& R. Wild), pp. 263-271. Routledge, London, UK.

Milner-Gulland, E.J., McGregor, J., Agarwala, M., Atkinson, G., Bevan, P., Clements, T. et al. (2014) Accounting for the impact of conservation on human well-being. Conservation Biology, 28, 1160-1166.

Mronyi, F.J., Estes, A.B., Msuha, M.J., Lichtenfeld, L.L. \& Durant, S.M. (2017) Local attitudes and perceptions toward large carnivores in a human-dominated landscape of northern Tanzania. Human Dimensions of Wildlife, 22, 314-330.

Mukhopadhyay, M. (2016) Mainstreaming gender or "streaming" gender away: feminists marooned in the development business. In The Palgrave Handbook of Gender and Development (ed. W. Hartcourt), pp. 77-91. Palgrave Macmillan, London, UK.

Mundoli, S., Gladwin, J. \& Setty, S. (2016) 'Shifting agriculture': the changing dynamics of Adivasi farming in the forest-fringes of a tiger reserve in South India. Agroecology and Sustainable Food Systems, 40, 759-882.

Nightingale, A.J. (2017) Environment and gender. In International Encyclopedia of Geography: People, the Earth, Environment and Technology (eds D. Richardson, N. Castree, M.F. Goodchild, A. Kobayashi, W. Liu \& R.A. Marston), pp. 1-13. Wiley-Blackwell, Hoboken, USA.

OGRA, M. (2008) Human-wildlife conflict and gender in protected area borderlands: a case study of costs, perceptions, and vulnerabilities from Uttarakhand (Uttaranchal), India.
Geoforum: Journal of Physical, Human, and Regional Geosciences, 39, 1408-1422.

OGRA, M. (2012) Gender and community-oriented wildlife conservation: views from project supervisors in India. Environment, Development and Sustainability, 14, 407-424.

Oldekop, J.A., Holmes, G., Harris, W.E. \& Evans, K.L. (2016) A global assessment of the social and conservation outcomes of protected areas. Conservation Biology, 30, 133-141.

Pascual, U., Phelps, J., Garmendia, E., Brown, K., Corbera, E., Martin, A. et al. (2014) Social equity matters in payments for ecosystem services. BioScience, 64, 1027-1036.

Rai, N.D., Benjaminsen, T.A., Krishnan, S. \& Madegowda, C. (2019) Political ecology of tiger conservation in India: adverse effects of banning customary practices in a protected area. Singapore Journal of Tropical Geography, 40, 124-139.

ReID, R. (2012) Savannas of Our Birth: People, Wildlife, and Change in East Africa. University of California Press, Berkeley, USA.

Rocheleau, D. (1991) Gender, ecology, and the science of survival: stories and lessons from Kenya. Agriculture and Human Values, $8,156-165$

Rocheleau, D., Thomas-Slayter, B. \& Wangari, E. (eds) (1996) Feminist Political Ecology: Global Issues and Local Experience. Routledge, London, UK.

Roque de Pinho, J., Grilo, C., Boone, R.B., Galvin, K.A. \& SNODGRASS, J.G. (2014) Influence of aesthetic appreciation of wildlife species on attitudes towards their conservation in Kenyan agropastoralist communities. PLOS ONE, 9, e88842.

Seager, J., Bowser, G. \& Dutta, A. (2021) Where are the women? Towards gender equality in the ranger workforce. Parks Stewardship Forum, 37, 206-218.

Setty, S., Kamalitt Bawa, S., Ticktin, T. \& MadeGowda, C. (2008) Evaluation of a participatory resource monitoring system for nontimber forest products: the case of amla (Phyllanthus spp.) fruit harvest by Soligas in South India. Ecology and Society, 13, 1-19.

Simpson, L.B. (2017) As We Have Always Done: Indigenous Freedom through Radical Resistance. University of Minnesota Press, Minneapolis, USA.

Thekaekara, T., Vanak, A.T., Hiremath, A.J., Rai, N.D., Ratnam, J. \& Sukumar, R. (2017) Notes from the other side of a forest fire. Economic \& Political Weekly, LII (25-26), 24-28.

Thompson, M. \& Homewood, K. (2002) Entrepreneurs, elites and exclusion in Maasailand: trends in wildlife conservation and pastoralist development. Human Ecology, 30, 107-138.

Venkatesh, A., Kusakabe, K. \& Veena, N. (2020) Indigenous people's response to the ban on use of forest resources in South India: a gender analysis of governmobility. Environment, Development and Sustainability, 22, 1489-1504.

Western, D., Wright, R.M. \& Strum, S. (eds) (1994) Natural Connections: Perspectives in Community-Based Conservation, Island Press, Washington, DC, USA.

Woodhouse, E. \& McCABE, J.T. (2018) Well-being and conservation: diversity and change in visions of a good life among the Maasai of northern Tanzania. Ecology and Society, 23, 43. 